Journal of Primary Education
$9(3)(2020): 238-247$
UNNES
https://journal.unnes.ac.id/sju/index.php/jpe

\title{
Implementation of Project -Based Learning Model (PjBL) Using STREAM-Based Approach in Elementary Schools
}

\author{
Wulan Aulia Azizah ${ }^{1 凶}$, Sarwi Sarwi ${ }^{2}$, Ellianawati Ellianawati ${ }^{2}$ \\ DOI: https://doi.org/10.15294/jpe.v9i3. 39950 \\ 1. Universitas Lambung Mangkurat, Kalimantan Selatan, Indonesia \\ 2. Pascasarjana, Universitas Negeri Semarang, Indonesia
}

\begin{tabular}{l}
\hline Article Info \\
\hline History Articles \\
Received: \\
5 February 2020 \\
Accepted: \\
10 March 2020 \\
Published: \\
31 May 2020 \\
\hline Keywords: \\
Creativity; Learning \\
Activity; PjBL; Social \\
skill; STEAM
\end{tabular}

\begin{abstract}
Learning in 21st Century focuses on the development of students learning activities in order to increase their creativity through creative products. This study aims to describe the implementation of Project-based Learning model using STREAM-based approach (Science, Technology, Religion, Engineering, Art, and Mathematics) on students learning activities and the results of creative products made by students. The research method used was descriptive qualitative. The data source was chosen using purposive sampling technique. The research subjects are 3 elementary schools in Banjarmasin city, amounting to 80 students. Data collection techniques were done through observation and product assesment. The results showed that the implementation of the $\mathrm{PjBL}$ model using STREAM-based approach had an effect on increasing the result of students learning up to 92.1 (very good), and their activeness in learning activities made them become more creative in designing an interesting product. In this study there were 4 creative products created by the students namely drip irrigation, water cycle, water quality test, and religious-based picture story booklets. The implication of this research is a great opportunity for teachers in elementary schools to use PjBL model using STREAM-based approach in order to increase students' interest, creativity, and social attitudes in learning.
\end{abstract}

\footnotetext{
Correspondence address:

Universitas Lambung Mangkurat, Kalimantan Selatan, Indonesia

E-mail: wulanauliaazizah@students.unnes.ac.id
} 


\section{INTRODUCTION}

Science learning in elementary schools occupies a strategic position because science education in 21st century is oriented towards developing students' intelligence in learning in order to solve problems in daily life. Based on the results of previous study, it was found that learning science as a process, attitude, and application in daily life become less attention in learning. Therefore, education in Indonesia should be student-centered and they do not only focus on memorizing but also required to be active in gaining knowledge in order to make learning become more meaningful.

Based on research conducted by (Owens et al., 2020). active learning is learning that can optimize all students' potential and provide meaningful learning by integrating knowledge, concepts, and skills in the learning process. Some research results showed that students learning activities can be seen based on 4 indicators, namely student enthusiasm for learning, student interaction with the teacher, student collaboration, and student active participation during learning (Dimyati \& Mudjiono, 2006; Susanti et al., 2017).

One indicator of the low quality of student' science learning can be seen from the results of a survey conducted by The Program for International Student Assessment (PISA) in 2019 which shows that the scientific ability of Indonesian' students is at a low level with a score of 396, ranking 67 out of 72 participating countries (OECD, 2019). Meanwhile, based on the results of observations done in 5 elementary schools in Banjarmasin city showed that the implementation of science learning in the classroom was less attractive, students' learning activities were less visible, and students were rarely given the opportunity to give their own opinions in solving problems given by the teacher.

Based on the results of research conducted by Sulistiyowati et al., (2018) revealed that the application of PJBL model using the integrated STEM was able to increase students' scientific literacy, especially in aspects of explaining the phenomenon of science. In addition, based on several research results show that PjBL STEM learning model is able to increase students learning activities, learning motivation, and provide real experiences for them to use science, technology, engineering, and mathematics in real contexts in order to prepare youth generation become ready to compete in the disruption era (Ismail et al., 2016; Tseng et al., 2013).

In Indonesia, the implementation of 2013 curriculum in elementary schools is integrated thematically so that the PjBL learning model with STEM integrated is the right model to support the implementation of 2013 Curriculum. $\mathrm{PjBL}$ learning with integrated STEM is an innovative learning model in the learning process, and creates a good learning environment so that students are able to solve problems exist in everyday life (Afriana et al., 2016; Lestari et al., 2018; Mutakinati et al., 2018).

The application of PjBL model with integrated STEM can be added with art and religion elements. According to Pilecki, T., \& Sousa, (2013) science and art complete each other, because science supports the tools needed for investigation or observation to produce an art, while art supports creativity, problem solving in the development of science. Meanwhile, the addition of religion element refers to the pillars of education held in Indonesia in order to achieve the goals of national education, namely learning to know, learning to do, learning to be, learning to live together in peace, as well as learning to strengthen faith, devotion, and noble character (Kemendikbud, 2013).

The results of research on the relationship between religion and science reveal that there is no contradiction between theology and science, because by linking religious aspects to science learning, it can encourage students to draw connections between knowledge possessed and applications in their lives as family members and religious communities (Agustina et al., 2017; Natsir, 2013). Therefore, learning science using the PjBL learning model with integrated STEM 
added with the aspects of art and religion is the right choice. The integration of these aspects can be approached with the $\mathrm{PjBL}$ learning model using Science, Technology, Religion, Engineering, Art, and Mathematics (STREAM) based approach.

Although aspects of art and religion provide an important role in enhancing students' science learning and creativity, the impact of the STREAM-based approach on students' activities and creative products has not been much revealed. Therefore, this study aims to explore the impact of Project-based Learning model using STREAM-based approach towards student activities, and the results of their creative products.

\section{METHODS}

The research method used in this study was descriptive qualitative which aimed to describe the implementation of PjBL model using STREAM-based approach towards students learning activities and the creative products of students in class $\mathrm{V}$ of Elementary School on the theme "Our Friends' Environment". This research was conducted in 4 meetings. The implementation of $\mathrm{PjBL}$ model using STREAM-based approach was carried out by making 4 creative product designs namely drip irrigation, water cycle, water quality test, and story booklet that were related to aspects of religion.

Sources of data in this study were chosen using a purposive sampling technique. Elementary school sampling was taken with the

\section{RESULTS AND DISCUSSION}

\section{Students Learning Activites}

Generally, the implementation of $\mathrm{PjBL}$ model using STREAM-based approach was criteria of using 2013 curriculum, schools that had $\mathrm{A}$ accreditation, schools that is piloting the implementation of the 2013 Curriculum, as well as schools that have similar facilities and infrastructure. The selected schools are 3 Banjarmasin sub-districts namely SDIT Ukhuwah Banjarmasin, SDN Karang Mekar 5 Banjarmasin, and SD Muhammadiyah 8 Banjarmasin. Data collection techniques were carried out through observation, and product assessment rubrics collected during the learning implementation.

The observation sheets and product assessment rubric were carried out by observing students learning activities. The aspects of students' activities were student learning enthusiasm, student collaboration in projects, active student participation, and active interaction between teachers and students. The assessment of students' creative products during learning was based on aspects of $\mathrm{PjBL}$ model using STREAM- based approach. The data obtained were then analyzed qualitatively through the stages of data reduction, data presentation, and drawing conclusion. Data reduction was obtained from observations, and product assessment sheets are reduced by summarizing, selecting, and focusing on the data in accordance with the research objectives. Presentation of data was done after data reduction. Data obtained from observation sheets and product assessment sheets were then presented in tabular form and narrative descriptions. Finally, data tables that have been reduced and presented were used to draw conclusions.

created into 4 aspects of student activities. assessment of the acquisition of a maximum score of 3 for each component and a score of 1 for the lowest score. The results can be seen in Table 1. 
Table 1. Observation Results of Student Activities

\begin{tabular}{lllllll}
\hline \multirow{2}{*}{ No } & \multirow{2}{*}{ School Code } & \multicolumn{4}{l}{ Aspects of students' learning activities } & \multicolumn{2}{l}{$\begin{array}{l}\text { Final } \\
\text { Average }\end{array}$} \\
\cline { 3 - 6 } & & 1 & 2 & 3 & 4 & 92.1 \\
\hline 1 & S01 & 84.6 & 94.2 & 90.3 & 98 & (Very Good) \\
2 & S02 & 84.6 & 92.3 & 96.1 & 94.2 & \\
3 & S03 & 82.6 & 92.3 & 96.1 & 100 & \\
\hline \multirow{2}{*}{ Average } & 83.9 & 92.9 & 94.2 & 97.4 & \\
& \multirow{2}{*}{ (Good) } & (Very & (Very & (Very & \\
& & & Good) & Good) & Good) & \\
\hline
\end{tabular}

When using the PjBL model using STREAM-based approach, students did not get all the knowledge from the teacher, but they played an active role in finding information about the material being studied. Learning was started by reciting the surah Al-Quran related to subject matter, after that the teacher linked with a problem in daily life. In addition, students discussed in groups to find information so that they can provide solutions to the problems encountered. During the discussion process, students were given a laptop as a learning support to get additional information related to the solutions they will provide.

Teacher assistance and technology during learning could make students' social attitudes improve. This can be seen through the increasing of students' enthusiasm in discussions when their friends expressed opinions or ideas related to learning and projects they made. The high learning enthusiasm of students had an impact on increasing cooperation and participation in their discussions. This can be seen in Table 1 which shows that overall student activities in the implementation of PjBL model using STREAM-based approach in three schools reached score up to 92.1 .

\section{PjBL Creative Products Using STREAM-based Approach}

The process of implementing the project of students' creative products can be seen based on elements in the STREAM (Science, Technology, Religion, Engineering, Art, and Mathematic) aspects that are found in the PjBL
Essentially, PjBL is a learning model that invites students to participate actively both individually and in groups, because through collaboration in groups students will involve in the problem-solving investigation process (Astuti et al., 2019). This becomes the foundation of the students' activities assessment aspects during the learning process, which shows that students are able to carry out each stage of the project properly in accordance with predetermined assessment criteria.

The use of the STREAM-based approach in learning is able to create an innovation or update students to discover or design new things. This is in accordance with the statement of Devi et al (2018) which revealed that STEM was able to improve learning skills to solve problems, design new things, do logical thinking and master information technology. Based on several studies explaining that the implementation of the STEM PjBL model encourages students to be actively involved in learning, improve students' social abilities, increase cognitive levels, and gives a positive impact on the mastery of the concept of learning because it requires students to actively complete the project undertaken (Park et al., 2016; Thuneberg et al., 2018).

model stage. The first aspect is related to students' scientific knowledge about water and environmental conservation materials. Activities in the Science aspect can be seen in Figure 1. 


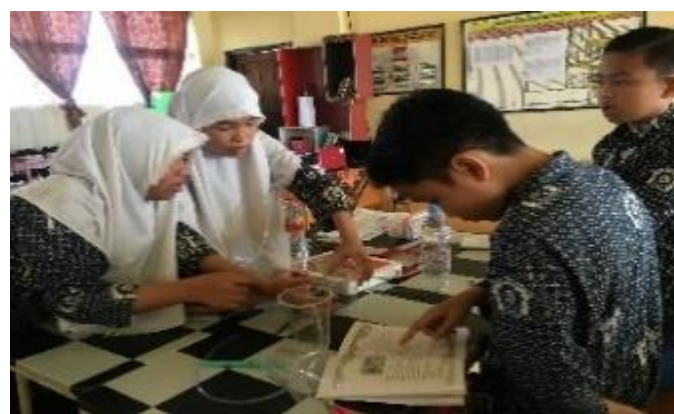

(a)

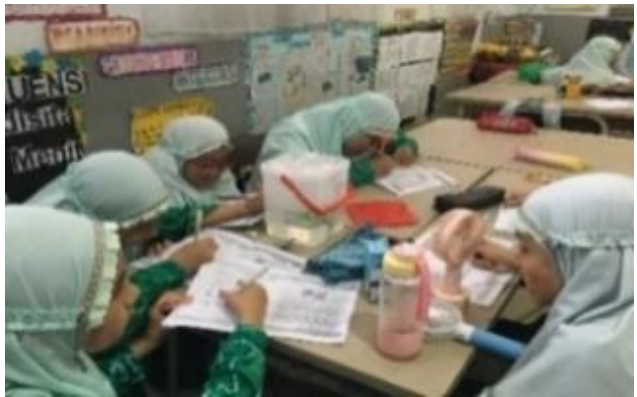

(b)

Figure 1. Science Aspects in Products of Drip Irrigation (a) and Water Cycle (b)

Based on the aspects of Science showed Figure 1, students were doing discussion in groups to identify the problems given by the teacher. It this Science Aspect, the first PjBL step appeared, namely the submission of essential questions. In this step, each group discussed and exchanged opinions to identify a problem from the questions given, In the discussion process, students were guided by using group worksheets to determine the right solution so that communication and

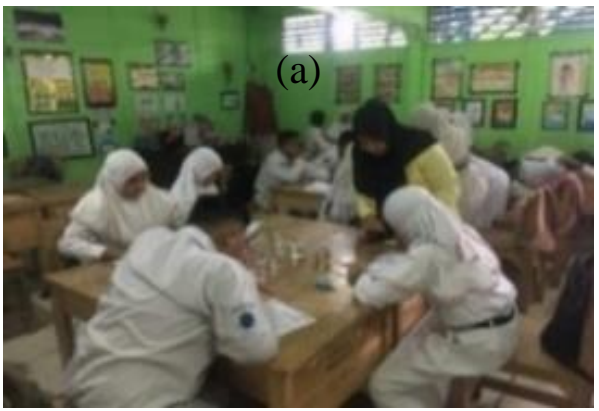

Figure 2. Technology Aspect in Product of Water Quality Test

In the technology aspect, the PjBL step that emerges is compiling project planning and schedule. In this step, each group was given laptop facilities to be able to access the internet to obtain information or knowledge needed related to the creative product to be made. Students were given the freedom to explore the information needed. In the aspect of technology, it seemed that students were very enthusiastic to use a laptop as a source of learning in addition to the teacher, books, and group friends. This was evidenced by the emergence of students' collaboration were strongly built within the group. The results of this study are then supported by previous research that explains the application of the PjBL using STEAM-based approach can make students actively involved in identifying problems (Hermanto et al., 2019; Kelley \& Knowles, 2016)

In the next stage, students confirmed the data and information by accessing the internet related to the project presented in Figure 2.

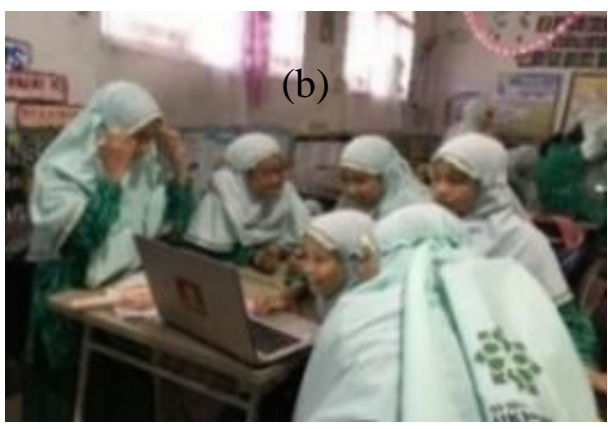

creative ideas to make products. This is in accordance with opinion from Gale et al., (2020) explained that the existence of technology can improve students' creativity and understanding of a problem.

The next PjBL stage was students designed creative products related to the Religion content as a support to foster their religious character. This is in line with 2013 curriculum about character education, and students' ability in integrating science and religion. An example of Religion aspect can be seen in 3. 
Di dalam Alquran surah Al. A'rat oyat 56 dijelasken mengensi larongar merusok lingkumgan

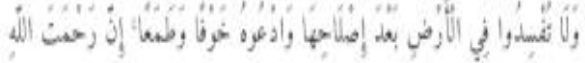

$$
\begin{aligned}
& \text { ز }
\end{aligned}
$$

Artinya: Dan jarganlah kamu membuat kerusakan di muka bumi, sessdah (Allah) memperbaikinya dan berdodah kepada-Nya derngan rasa takut (tidak akan diterina) dan haropan (aken dikabulkan). Sessnggehnyo rehtrat Alloh anot dekat kepada areng-orang yang berbuat baik.

(a)

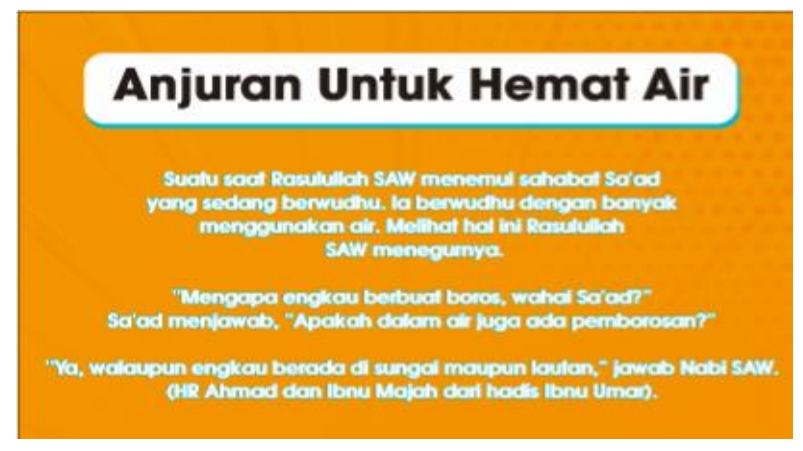

(b)

Figure 3. Religion Aspect: Link learning with Islam

In the religion aspect, the stages of the PjBL carried out namely monitoring students' work and their project progress and at the same time they did self-evaluation based on their experience in working on the project. In its implementation, each group made a religiousbased booklet related to the theme "Water" as a form of environmental conservation, especially to preserve water. In the Religion aspect, each group connected learning material to the attitudes they must have in the context of implementing the knowledge they already have. In science learning related to water conservation which is associated with religious aspects including the Prophet's advice to save water when performing ablution, preserve water, and help each other in doing good deeds. In this aspect, students' discussion became more meaningful because there was a feeling of gratitude and religious character was formed. This is in line with research that explained that the addition of religious elements in learning has a positive influence on learning activities and students' mastery concepts (Khoiri et al., 2017).

Students' knowledge that was integrated with religious knowledge was then directed to the stage of making product designs that have been planned in each group called the aspects of Engineering. The process of the Engineering aspect can be seen in Figure 4 .

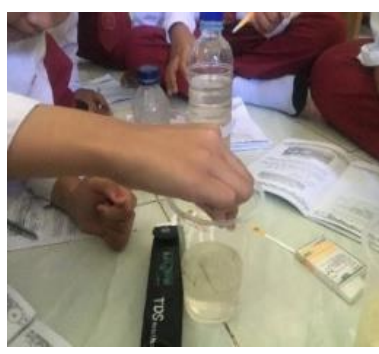

(a)

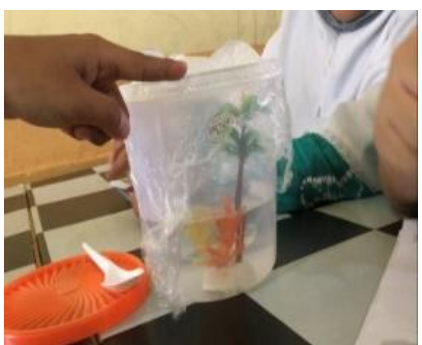

(b)

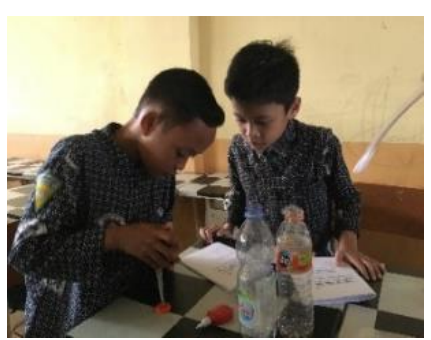

(c)

Figure 4. Engineering aspects on the Project of Water Quality Test (a), Water Cycle (b), and Drip Irrigation (c)

At the engineering stage, the PjBL step was when monitoring students and project progress. In its implementation, the teacher encourages students in each group to discuss making or designing products with the help of appropriate information about creative ideas.
During the implementation of the engineering process, many trials and errors were naturally occurred in each group. In this case, the teacher played an important role in providing support to students and explained to them that mistakes were common in designing a product. During 
the engineering process, each group was busy in analyzing and interpreting data that had been collected from the previous stages to find the optimal design solution. This result was supported by research conducted by Engelman et al., (2017) which explains that the application of PjBL STEM makes students become more careful and enthusiastic in the learning process.

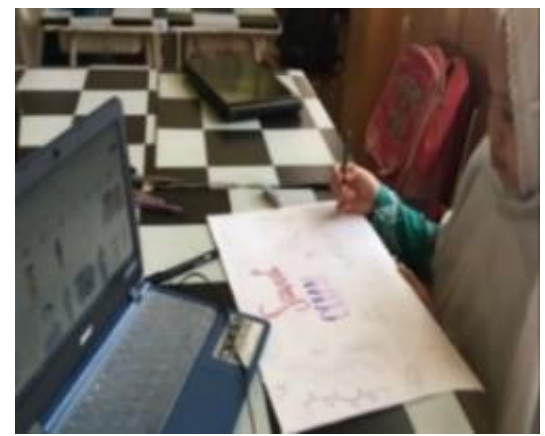

(a)
After the engineering phase has been completed, the teacher asked students to create pictures stories related to the material that has been learned and still in line to SBdP material in class V of Elementary School. This aspect was called art. The process of mplementing the art aspect can be seen in Figure 5

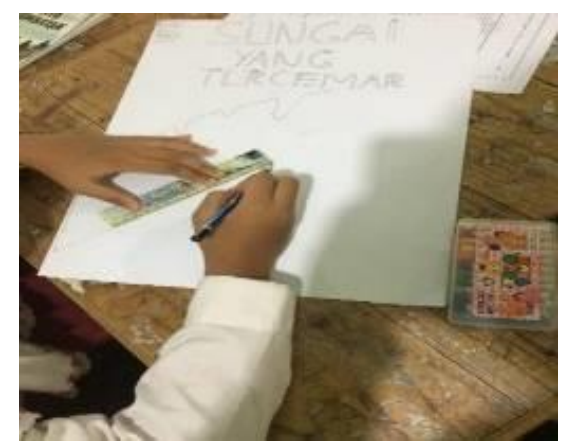

(b)

Figure 5. Art Aspect: Making a picture booklet related to learning and religious aspects.

In the art aspect, the stages of the $\mathrm{PjBL}$ step happened when monitoring students and project progress, as well as evaluating results. In the learning process, each group was facilitated with a laptop connected to the internet to find information and ideas in making a picture booklet. In its process, students associated verses of the Qur'an or hadith related to environmental themes and water conservation. During the art process, students were very enthusiastic in exploring their imagination to draw pictures stories related to the knowledge they had learned. This can be seen from the imaginative and inspirational picture titles made by each group to protect the environment. This result is in line with several previous studies which

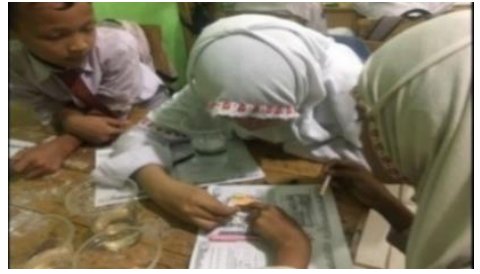

(a) explain that the application of $\mathrm{PjBL}$ model using STREAM-based approach is able to increase students' activity, especially creativity that makes them enjoy the learning process (Allina, 2018; Perignat \& Katz-Buonincontro, 2018).

During the learning process takes place, among the aspects of Science, Technology, Religion, Engineering, and Art were certainly not separated from the mathematics aspects. The mathematics aspect could be seen when students measured the water $\mathrm{pH}$ and TDS (Total Dissolve Solid) or commonly called the amounts of solids dissolved in various types of water carried by each group that can be seen in Figure 6.

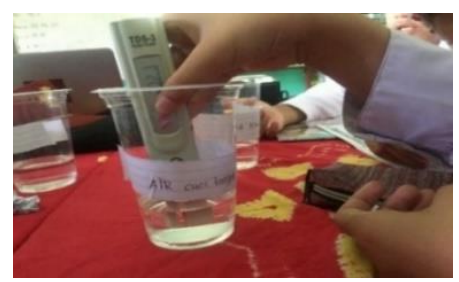

(b)

Figure 6. Mathematics Aspect: Students measure water $\mathrm{Ph}(\mathrm{a})$ and TDS water content (b) 
In the mathematics aspect, the stages of the PjBL undertaken was monitoring students and the progress of the project, as well as evaluating results. In the learning process, it could be seen that students were calculating the $\mathrm{pH}$ or acidity of each water type they carry in each group. After calculating the $\mathrm{Ph}$, each group was also asked to measure the TDS content contained in the water. After determining the $\mathrm{Ph}$ and TDS of every type of water carried by each group, they started to determine which type of water that is suitable to be consumed and can be used for other household needs. In the mathematics aspect, students looked so enthusiastic to calculate water discharge, as well as the $\mathrm{Ph}$ and TDS of water content. This result was relevant to Li \& Schoenfeld (2019) that mathematics learning will become more interesting and meaningful if implemented through PjBL model using integrated STEM.

Based on the analysis of creative products produced by students during the learning process, there were 13 indicators of students' creative products assessment with a maximum score 4 and the minimum score 1 . The results of students' creative products assessment can be seen in Table 2 .

Table 2. The Results of Students' Creative Product Assessment

\begin{tabular}{lllllll}
\hline \multirow{2}{*}{ Aspect } & \multicolumn{2}{l}{ Creative Product Assessment } & & \\
\cline { 2 - 5 } & $\begin{array}{l}\text { Drip } \\
\text { irrigation }\end{array}$ & $\begin{array}{l}\text { Water } \\
\text { cycle }\end{array}$ & $\begin{array}{l}\text { Water } \\
\text { quality } \\
\text { test }\end{array}$ & $\begin{array}{l}\text { Buklet cerita } \\
\text { bergambar }\end{array}$ & $\begin{array}{l}\text { Score } \\
\text { Difference }\end{array}$ & Description \\
\hline Science & 78 & 89 & 89 & 94 & 17 & Increase \\
Technology & 83 & 96 & 98 & 100 & 17 & Increase \\
Religion & 75 & 88 & 88 & 96 & 21 & Increase \\
Engineering & 83 & 92 & 92 & 100 & 17 & Increase \\
Art & 79 & 88 & 92 & 100 & 21 & Increase \\
Mathematic & 83 & 92 & 92 & 100 & 17 & Increase \\
\hline
\end{tabular}

Based on the information from Table 2, it can be revealed that overall assessment of students' creative products increased in each meeting. This was also supported by the teacher's role in providing scaffolding to students. Small assistance given by the teacher to students would increase their confidence when their project framework was able to guide them to find solutions towards the problems. When students are able to find the right solution, they will be given the freedom to complete creative product manufacturing projects in accordance with a predetermined time. In practice, this made students become free to follow their interests and abilities to make products creatively. As a result, the students' knowledge was increasing and became more meaningful for them by changing abstract concepts into reality through the creation of useful creative products.

The results of this study are in line with the result of several previous studies which explaining that the application of PjBL model with integrated STEM has some advantages. PjBL model gave opportunities to students to be able in understanding concepts by making products, whereas in using STEM-based approach there was a design and redesign (engineering design process) process. Both an integration make students become able to produce creative and innovative products (Afifah \& Ellianawati, 2019; Astuti et al., 2019).

The most prominent improvement of students' creative products assessment was the assessment of religion and art aspects. This increase was affected by the presence of religion and art elements in STEM-based approach in the process of product manufacturing, so students were able to identify a contextual problem related to the product would be made through discussion. Active discussion can build communication, collaboration, social attitudes 
and creativity among students to become more interesting and meaningful.

This is supported by several studies that explain that the ability to thinking, creativity, and student' learning outcomes can be increased by adding aspects of religion into learning (Khoiri et al., 2017; Yusnita et al., 2016). In addition, based on several studies explain that the addition of art aspects to the PjBL model integrated sTEM can increase students'enthusiasm, increase student creativity in science, and increase student interest in science learning (Perignat \& Katz-Buonincontro, 2018; Pilecki, T., \& Sousa, 2013).

This study confirmed that students' creative products using $\mathrm{PjBL}$ model of STREAM-based approach are more optimal than just using PjBL model of integrated STEM.

\section{CONCLUSION}

The results of this study are there is a significant influence on the application of the PjBL model using STREAM-based approach towards students' learning activities as well as the results of their creative products. The addition of religion and art elements to the STEM approach in thematic learning can make students be able to design more varied products and improve their social attitudes. In addition, religion aspect that are associated with verses of Al-Qurán and hadith can make students more easily to represent their way of thinking to determine a solutions and opinions when doing discussion.

\section{REFERENCES}

Afifah, R., \& Ellianawati, E. (2019). Student Cognitive Profile with STEM Based Teaching Material on the Subject of Vibrations and Waves. Jurnal Penelitian \& Pengembangan Pendidikan Fisika, 5(2), 217226.

Afriana, J., Permanasari, A., \& Fitriani, A. (2016). Project Based Learning Integrated to STEM to Enhance Elementary School's Students Scientific Literacy.
Jurnal Pendidikan IPA Indonesia, 5(2), 261267.

Agustina, T. W., Rustaman, N. Y., \& Purwaningsih, W. (2017). The Learning of Compost Practice in University. Journal of Physics: Conference Series, 895(1), 012128

Allina, B. (2018). The development of STEAM educational policy to promote student creativity and social empowerment. Arts Education Policy Review, 119(2), 77-87.

Astuti, Ines Dewi, Toto, \& Yulisna, L. (2019). Model Project Based Learning (PjBL) Terintegrasi STEM untuk Meningkatkan Penguasaan Konsep dan Aktivitas Belajar Siswa. Jurnal Pendidikan Dan Biologi, 11(2), 93-98.

Devi, P. K., Herliani, E., Setiawan, R., Yanuar, Y., \& Karyana, S. (2018). Materi Bimbingan Teknis Pembelajaran Berbasis STEM Dalam Kurikulum 2013 STEM Mata Pelajaran IPA. Direktorat Pembinaan Sekolah Menengah Pertama.

Dimyati, \& Mudjiono. (2006). Belajar dan Pembelajaran. PT Rineka Cipta.

Engelman, S., Magerko, B., McKlin, T., Miller, M., Edwards, D., \& Freeman, J. (2017). Creativity in authentic STEAM education with Earsketch. Proceedings of the Conference on Integrating Technology into Computer Science Education, ITiCSE, 183188.

Gale, J., Alemdar, M., Lingle, J., \& Newton, S. (2020). Exploring critical components of an integrated STEM curriculum: an application of the innovation implementation framework. International Journal of STEM Education, 7(5), 1-17.

Hermanto, I., Sarwi, S., \& Yusuf, A. (2019). The Effectiveness of Project-based Learning Model to Develop Students ' Social Skills. Journal of Primary Education, 10(2), 173-180.

Ismail, Permanasari, A., \& Setiawan, W. (2016). STEM Virtual Lab: An Alternative Practical Media to Enhance Student's Scientific Literacy. Jurnal Pendidikan IPA Indonesia, 5(2), 239-246.

Kelley, T. R., \& Knowles, J. G. (2016). A conceptual framework for integrated STEM education. International Journal of STEM Education, 3(11), 1-11.

Kemendikbud. (2013). Materi pelatihan Implementasi Kurikulum 2013. Kemendikbud.

Khoiri, A., Agussuryani, Q., \& Hartini, P. (2017). Penumbuhan Karakter Islami 
melalui Pembelajaran Fisika Berbasis Integrasi Sains-Islam. Tadris: Jurnal Keguruan Dan Ilmu Tarbiyah, 02(1), 19-31.

Lestari, T. P., Sarwi, S., \& Sumarti, S. S. (2018). STEM-Based Project Based Learning Model to Increase Science Process and Creative Thinking Skills of 5th Grade. Journal of Primary Education, 7(1), 18-24.

Li, Y., \& Schoenfeld, A. H. (2019). Problematizing teaching and learning mathematics as " given " in STEM education. International Journal of STEM Education, 6(44), 1-13.

Mutakinati, L., Anwari, I., \& Yoshisuke, K. (2018). Analysis of Students' Critical Thinking Skill of Middle School through STEM Education Project-based Learning. Jurnal Pendidikan IPA Indonesia, 7(1), 5465.

Natsir, N. (2013). Paradigma Wahyu Memandu Ilmu dalam Pembidangan Ilmu-Ilmu Keislaman.

http://www.uinsgd.ac.id/front/detail/m engenal_tokoh/nanat-fatah-natsir

OECD. (2019). PISA 2018 Results Combined Executive Summaries. https://www.oecd.org/pisa/Combined Executive_Summaries_PISA_2018.pdf

Owens, D. C., Sadler, T. D., Barlow, A. T., \& Smith-Walters, C. (2020). Student Motivation from and Resistance to Active Learning Rooted in Essential Science Practices. Research in Science Education, 50(1), 253-277.

Park, H., Byun, S. Y., Sim, J., Han, H., \& Baek, Y. S. (2016). Teachers' perceptions and practices of STEAM education in South Korea. Eurasia Journal of Mathematics, Science and Technology Education, 12(7), 1739-1753.
Perignat, E., \& Katz-Buonincontro, J. (2018). From STEM to STEAM: Using BrainCompatible Strategies to Integrate the Arts. Arts Education Policy Review, 119(2), 107-110.

Pilecki, T., \& Sousa, D. A. (2013). From STEM to STEAM: Using Brain-Compatible Strategies to Integrate the Arts. Corwin.

Sulistiyowati, Abdurrahman, \& Jalmo, $\mathrm{T}$. (2018). The Effect of STEM-Based Worksheet on Students , Science Literacy. Tadris: Jurnal Keguruan Dan Ilmu Tarbiyah, 3(1), 89-96. https://doi.org/10.24042/tadris.v3i1.214 1

Susanti, Y., Wahjoedi, W., \& Utaya, S. (2017). Peningkatan Aktivitas dan Hasil Belajar Siswa Melalui Pembelajaran Kooperatif Tipe STAD. Jurnal Pendidikan: Teori, Penelitian, Dan Pengembanga, 2(5), 661666.

Thuneberg, H. M., Salmi, H. S., \& Bogner, F. X. (2018). How creativity, autonomy and visual reasoning contribute to cognitive learning in a STEAM hands-on inquirybased math module. Thinking Skills and Creativity, 29(April), 153-160.

Tseng, K. H., Chang, C. C., Lou, S. J., \& Chen, W. P. (2013). Attitudes towards science, technology, engineering and mathematics (STEM) in a project-based learning (PjBL) environment. International Journal of Technology and Design Education, 23(1), 87-102.

Yusnita, I., Masykur, R., \& Suherman. (2016). Modifikasi Model Pembelajaran Gerlach Dan Ely Melalui Integrasi Nilai-Nilai Keislaman Sebagai Upaya Meningkatkan Kemampuan Representasi Matematis. AlJabar: Jurnal Pendidikan Matematika, 7(1), 41-54. 